http://www.pakjas.com.pk

\title{
ASSESSMENT OF ACUTE METALS TOXICITY IN Catla catla THROUGH HEMATOLOGICAL AND BIOCHEMICAL BLOOD MARKERS
}

\author{
Wardah Hassan $^{\text {* }}$, Sajid Abdullah ${ }^{1}$, Muhammad Afzal ${ }^{1}$ and Mumtaz Hussain ${ }^{2}$ \\ ${ }^{1}$ Department of Zoology, Wildlife \& Fisheries, University of Agriculture, Faisalabad, Pakistan; \\ ${ }^{2}$ Department of Botany, University of Agriculture, Faisalabad, Pakistan. \\ "Corresponding author's e-mail: wardahhassan1@ hotmail.com
}

\begin{abstract}
The objective of the current study was to determine the toxicological effects of acute cadmium (Cd) and copper $(\mathrm{Cu})$ exposure on hematological and serum biochemical parameters of major carp, Catla catla. The experimental group of fish were exposed to $\mathrm{Cd}$ and $\mathrm{Cu}$ for 24-, 48-, 72- and 96-hr. The hematological analysis of exposed fish at all exposure durations exhibited significant decrease in red blood cells count, hemoglobin and hematocrit content while marked elevation in white blood cells count, mean cell volume, mean cell hemoglobin and mean cell hemoglobin concentration was recorded in comparison to control. Among serum biochemical parameters, the level of sodium, chloride, albumin and total protein was lower at all exposure durations of metals. However, potassium, urea, glucose, aspartate aminotransferase and alanine aminotransferase levels were noticeably higher in serum of treated fish. Results also indicated that $\mathrm{Cu}$ has more toxic effects on hematological and serum biochemical parameters than $\mathrm{Cd}$. This study proposed that the occurrence of toxic metals in aquatic environment has significant impact on the hematological and serum biochemical parameters in $C$. catla. The observed changes in these parameters may provide valuable information for further concerning environmental conditions and risk assessment of aquatic organisms.
\end{abstract}

Keywords: Hematology, serum biochemistry, metals, Catla catla, toxicological effects.

\section{INTRODUCTION}

Heavy metals constitute a major group of aquatic contaminants and their large amount accumulates in aquatic ecosystems as a consequence of land based activities (Vutukuru, 2003). Among metals, cadmium (Cd), one of the most dangerous environmental pollutant because of its tendency to bio-accumulate in living organisms raises environmental concern (Liao et al., 2011; Sfakianakis et al., 2015). The use of $\mathrm{Cd}$ containing agricultural chemicals, pesticides, fertilizers and sewage sludge in farm land, might also enhance to the water contamination (ATSDR, 2003). Survival rate of aquatic organisms is affected due to the exposure to $\mathrm{Cd}$ and leads to a gradual extinction of their generations in polluted water (Sridhara et al., 2008). Although copper $(\mathrm{Cu})$ is essential to the health of all living organisms as it is involved in several fundamental biological processes however, it proves disastrous to aquatic organisms when it surpasses the normal limits. Its toxicity to aquatic organisms had previously been described by several workers (Paquin $e t$ al., 2002; Dhanapakiam et al., 2006; Ketpadung and Tangkrock-Olan, 2006; Isani et al., 2013). Copper sulphate $\left(\mathrm{CuSO}_{4}\right)$ is generally used as an algaecide as well as an herbicide in aquatic weed control (Carbonell and Tarazona, 1993).

Fishes are the animals that cannot escape from the negative effects of these contaminants and prove as good bio- indicators of aquatic pollution (Pandey, 2013). Fish blood is being studied increasingly in environmental monitoring and toxicological research as a potential indicator of pathological and physiological changes in disease investigations and fishery management (Remyla et al., 2008). Numerous studies have showed that metals, for instance cadmium and copper induce changes in blood parameters of fish (Kotsanis et al., 2000; Mazon et al., 2003; Ajani and Akpoilih, 2010; AlGhanim, 2011; Sayed and Shokr, 2015).

Numerous hematological indices, for instance hemoglobin, hematocrit, white blood cells, red blood cells, mean cell volume, mean cell hemoglobin and mean cell hemoglobin concentration have been used as indicators of metal contamination in the aquatic ecosystem (Kavitha et al., 2010). Measurement of serum biochemical parameters such as aspartate aminotransferase, alanine aminotransferase, ions, total protein and glucose is valuable to ascertain the toxicity of target organs along with the overall health status of animals (Kori-Siakpere et al., 2012).

In fisheries management program hematology and serum biochemistry data are of great importance to monitor the health status of aquatic animals (Skjervold et al., 2001). Accordingly, the objective of this study was to investigate the effects of acute cadmium and copper exposure for varying durations on hematological and serum biochemical parameters as sensitive indices for the evaluation of fish 
physiology under metallic stress in economically important fish (Catla catla) of Pakistan.

\section{MATERIALS AND METHODS}

The present experiment was conducted in the Wet Laboratory of Fisheries Research Farms, Department of Zoology, Wildlife and Fisheries, University of Agriculture, Faisalabad. Catla catla of desired weight $(30 \mathrm{~g})$ were obtained from the Fish Seed Hatchery, Faisalabad. They were brought to the Wet Laboratory and acclimatized to the laboratory conditions for 14 days.

Pure chloride compounds of cadmium $\left(\mathrm{CdCl}_{2} \cdot \mathrm{H}_{2} \mathrm{O}\right)$ and copper $\left(\mathrm{CuCl}_{2} .2 \mathrm{H}_{2} \mathrm{O}\right)$ were used in this experiment and stock solutions were prepared for required metal dilution. Fish were exposed for $96-\mathrm{hr}$ to waterborne lethal concentrations $\left(\mathrm{LC}_{50}\right)$ of metals which were already determined by Yaqub and Javed (2012), and Kousar and Javed (2015). The water temperature $\left(30^{\circ} \mathrm{C}\right), \mathrm{pH}(7)$ and total hardness $(225 \mathrm{mg} / \mathrm{L})$ of the test media were kept constant. Total ammonia, sodium, potassium, magnesium, carbon dioxide and calcium contents of the test media were monitored on daily basis by following the methods of A. P. H. A. (1998).

Hematological parameters: The blood samples were taken at different time intervals (24-, 48-, 72- and 96-hr) from metals exposed and control fishes to study the hematological and serum biochemical parameters. Specimens with an average body weight of $30 \mathrm{~g}$ (ranged from 27 to $34 \mathrm{~g}$ ) were used for sample collection. After anaesthetizing the fish with MS-222 $(100 \mathrm{mg} / \mathrm{L})$, blood samples were collected under sterile conditions by the puncture of caudal vein with a heparincoated 23-gauge needle attached to a $2.5 \mathrm{~mL}$ syringe. The hematological parameters i.e. red blood cells, hemoglobin, hematocrit, white blood cells, mean cell volume, mean cell hemoglobin and mean cell hemoglobin concentration were determined by using automated cell counter (Sysmex KX 21). Serum biochemical parameters: Blood samples for serum biochemical analysis were collected without an anticoagulant. The blood samples were left for 1-hr on ice and then centrifuged at $3000 \mathrm{rpm}$ for 10 minutes to isolate the serum. Samples were stored at $-80^{\circ} \mathrm{C}$ before the further analysis. Serum biochemical parameters (sodium, potassium, chloride, albumin, total protein, urea, urea, aspartate aminotransferase, alanine aminotransferase) were estimated following standard methods using commercially available kits by BioMed Company.

Statistical analysis: Data were reported as mean \pm S.D. $(n=3)$. Significance of samples means $(\mathrm{p}<0.05)$ between control and metals exposed fish were measured using Sudent's T-Test by SPSS.

\section{RESULTS AND DISCUSSION}

Hematological parameters: Clinical blood indices have been extensively used as effective bioindicators in aquatic toxicology (Singh and Srivastava, 2010). These indices are very crucial for the assessment of fish physiological status under metal stress. The hematological parameters in C. catla exposed to $96-\mathrm{hr} \mathrm{LC}_{50}$ of cadmium $(\mathrm{Cd})$ and copper $(\mathrm{Cu})$ are given in Table 1. RBCs, $\mathrm{Hb}$ and Hct contents of the fish exposed to either $\mathrm{Cd}$ or $\mathrm{Cu}$ were significantly decreased as compared to control at the end of all the exposure periods. However, the percent decrease in the RBCs, $\mathrm{Hb}$ and Hct content was relatively high i.e. $-45.90,-26.95$ and $-40.26 \%$, respectively in $\mathrm{Cu}$ exposed fish and $39.75,-17.73$ and -31.02 $\%$, respectively in Cd exposed fish after 96-hr exposure.

Similar result was also detected in $O$. mykiss exposed to $\mathrm{Pb}$ and $\mathrm{Cu}$ (Ates et al., 2008). The authors reported that decrease in these parameters indicates the anemic condition of the fish which inhibit the blood formation in blood forming organs. Production of reactive oxygen species caused by metals may be another potential cause for the noticed decline in $\mathrm{Hb}$ content (Larsson et al., 1985). Failure of red blood cell production, impaired osmoregulation or internal bleeding under stress condition may lead to decrease in number of RBCs (Kavitha et al., 2010). Furthermore, lower Hct content also designates contraction of cell as a result of toxicant stress on erythropoietic tissue (Saravanan et al., 2011). The high concentrations of metals for short term exposure usually declines the above mentioned parameters. Previous studies also reported a decline in RBCs, $\mathrm{Hb}$ and Hct content in freshwater fishes exposed to $\mathrm{Cd}$ and $\mathrm{Ni}$ showing anemia, leucopoiesis and erythropenia (Vincent et al., 1996; Nanda and Behera, 1996).

White blood cells (WBCs) increased significantly $(\mathrm{p}<0.05)$ in both $\mathrm{Cd}$ and $\mathrm{Cu}$ treated fish as compared to control. The MCV increased gradually from $24-\mathrm{hr}$ to $96-\mathrm{hr}$ exposure duration. A significant $(\mathrm{p}<0.05)$ increase in $\mathrm{MCH}$ and $\mathrm{MCHC}$ was also observed in metal treated fish as compared to control. The percent increase in WBCs, MCV, MCH and MCHC over control was relatively higher in $\mathrm{Cu}$ exposed fish as compared to Cd exposed.

In current study, the increase in WBCs indicates a defensive response to the metals exposure (Abhijith et al., 2012). Nevertheless, the detected rise in MCV and $\mathrm{MCH}$ during lethal exposure designates the macrocytic anemia (Saravanan et al., 2011). Furthermore, high number of smaller undeveloped RBCs in blood due to hyperplasia in the erythropoietic sites also leads to higher MCV (Ferrando and Andreu-Moliner, 1991). However, the detected increase of MCHC during lethal exposure may be owing to genetic sphaerocytosis (Sobecka, 2001).

Biochemical parameters: The effect of metals on serum biochemical parameters of $C$. catla exposed to the $\mathrm{Cd}$ and $\mathrm{Cu}$ for 24-, 48-, 72- and 96-hr is illustrated in Figure 1. In ecotoxicology serum ion levels are considered as good biomarkers because these can easily alter as a result of reduced intestinal fluid absorption, reduced branchial ion 
Metals toxicity in Catla catla

Table 1. Hematological parameters of Catla catla in control and metal exposed fish.

\begin{tabular}{|c|c|c|c|c|c|c|}
\hline $\begin{array}{l}\text { Hematological } \\
\text { parameters }\end{array}$ & $\begin{array}{l}\text { Exposure } \\
\text { duration }\end{array}$ & Control & Cu exposure & Percent Change & Cd exposure & Percent Change \\
\hline \multirow[t]{4}{*}{ RBCs $\left(10^{6} / \mu \mathrm{L}\right)$} & 24-hr & $2.43 \pm 0.39$ & $1.75 \pm 0.49^{*}$ & $(-27.98)$ & $1.98 \pm 0.47^{*}$ & $(-18.52)$ \\
\hline & $48-\mathrm{hr}$ & $2.43 \pm 0.50$ & $1.59 \pm 0.58^{*}$ & $(-34.57)$ & $1.78 \pm 0.38^{*}$ & $(-26.75)$ \\
\hline & 72-hr & $2.44 \pm 0.59$ & $1.47 \pm 0.36^{*}$ & $(-39.75)$ & $1.70 \pm 0.56^{*}$ & $(-30.33)$ \\
\hline & 96-hr & $2.44 \pm 0.61$ & $1.32 \pm 0.47^{*}$ & $(-45.90)$ & $1.47 \pm 0.32^{*}$ & $(-39.75)$ \\
\hline \multirow{4}{*}{$\mathrm{Hb}(\mathrm{g} / \mathrm{dL})$} & 24-hr & $5.63 \pm 0.41$ & $4.67 \pm 0.78^{*}$ & $(-17.05)$ & $5.03 \pm 0.72^{*}$ & $(-10.66)$ \\
\hline & $48-\mathrm{hr}$ & $5.63 \pm 0.43$ & $4.52 \pm 0.95^{*}$ & $(-19.72)$ & $4.95 \pm 0.87^{*}$ & $(-12.08)$ \\
\hline & 72-hr & $5.64 \pm 0.69$ & $4.32 \pm 0.61^{*}$ & $(-23.40)$ & $4.70 \pm 0.61^{*}$ & $(-16.67)$ \\
\hline & 96-hr & $5.64 \pm 0.77$ & $4.12 \pm 1.18^{*}$ & $(-26.95)$ & $4.64 \pm 0.61^{*}$ & $(-17.73)$ \\
\hline \multirow{4}{*}{ Hct $(\%)$} & 24-hr & $25.11 \pm 1.06$ & $19.00 \pm 1.44^{*}$ & $(-24.33)$ & $21.00 \pm 1.08^{*}$ & $(-16.37)$ \\
\hline & $48-\mathrm{hr}$ & $25.11 \pm 1.44$ & $17.35 \pm 1.27^{*}$ & $(-30.90)$ & $19.76 \pm 1.08^{*}$ & $(-21.31)$ \\
\hline & 72-hr & $25.11 \pm 1.06$ & $16.67 \pm 1.12^{*}$ & $(-33.61)$ & $18.65 \pm 1.47^{*}$ & $(-25.73)$ \\
\hline & 96-hr & $25.11 \pm 1.02$ & $15.00 \pm 1.05^{*}$ & $(-40.26)$ & $17.32 \pm 1.22^{*}$ & $(-31.02)$ \\
\hline \multirow{4}{*}{ WBCs $\left(10^{3} / \mu \mathrm{L}\right)$} & 24-hr & $29.98 \pm 1.54$ & $39.98 \pm 1.39^{*}$ & $(+33.36)$ & $35.54 \pm 1.40^{*}$ & $(+18.55)$ \\
\hline & $48-\mathrm{hr}$ & $29.16 \pm 1.48$ & $41.78 \pm 1.77^{*}$ & $(+43.28)$ & $37.55 \pm 1.32^{*}$ & $(+28.77)$ \\
\hline & 72-hr & $29.67 \pm 1.60$ & $45.12 \pm 1.31^{*}$ & $(+52.07)$ & $39.67 \pm 1.50^{*}$ & $(+33.70)$ \\
\hline & 96-hr & $29.67 \pm 1.97$ & $48.26 \pm 1.98^{*}$ & $(+62.66)$ & $42.59 \pm 1.56^{*}$ & $(+43.55)$ \\
\hline \multirow[t]{4}{*}{ MCV (fL) } & 24-hr & $104.44 \pm 11.72$ & $113.67 \pm 28.71^{*}$ & $(+8.84)$ & $109.26 \pm 19.28$ & $(+4.62)$ \\
\hline & 48-hr & $105.30 \pm 14.37$ & $116.83 \pm 31.87^{*}$ & $(+10.95)$ & $113.92 \pm 18.82^{*}$ & $(+8.19)$ \\
\hline & 72-hr & $106.45 \pm 20.99$ & $120.33 \pm 40.67^{*}$ & $(+13.04)$ & $116.81 \pm 31.53^{*}$ & $(+9.73)$ \\
\hline & 96-hr & $106.43 \pm 20.34$ & $122.13 \pm 39.41^{*}$ & $(+14.75)$ & $120.90 \pm 21.78^{*}$ & $(+13.60)$ \\
\hline \multirow[t]{4}{*}{$\mathrm{MCH}(\mathrm{pg})$} & 24-hr & $23.36 \pm 2.19$ & $27.42 \pm 4.27^{*}$ & $(+17.38)$ & $25.79 \pm 2.32^{*}$ & $(+10.40)$ \\
\hline & 48-hr & $23.54 \pm 2.78$ & $29.42 \pm 4.32^{*}$ & $(+24.98)$ & $28.00 \pm 1.13^{*}$ & $(+18.95)$ \\
\hline & 72-hr & $23.66 \pm 3.28$ & $30.08 \pm 3.81^{*}$ & $(+27.13)$ & $29.08 \pm 6.28^{*}$ & $(+22.91)$ \\
\hline & 96-hr & $23.65 \pm 3.60$ & $31.64 \pm 2.16^{*}$ & $(+33.78)$ & $32.05 \pm 3.46^{*}$ & $(+35.52)$ \\
\hline \multirow[t]{4}{*}{$\operatorname{MCHC}(\mathrm{g} / \mathrm{dL})$} & 24-hr & $22.41 \pm 0.76$ & $24.48 \pm 2.27$ & $(+9.24)$ & $23.86 \pm 2.20$ & $(+6.47)$ \\
\hline & 48-hr & $22.40 \pm 0.46$ & $25.88 \pm 3.86^{*}$ & $(+15.54)$ & $24.92 \pm 3.08^{*}$ & $(+11.25)$ \\
\hline & 72-hr & $22.43 \pm 1.90$ & $26.16 \pm 5.30^{*}$ & $(+16.63)$ & $25.13 \pm 1.31^{*}$ & $(+12.04)$ \\
\hline & 96-hr & $22.42 \pm 2.22$ & $27.29 \pm 6.45^{*}$ & $(+21.72)$ & $26.72 \pm 1.79^{*}$ & $(+19.18)$ \\
\hline
\end{tabular}

Data represents mean \pm S.D. $(n=3), *$ Significant, $p<0.05$ (Based on $t$ test).

(-) Denotes percent decrease over control, (+) Denotes percent increase over control.

extrusion and alterations in the morphological structure of the cells (Oner et al., 2008). The present study exhibited significantly lower level of $\mathrm{Na}$ in serum of metal exposed fish in comparison to control. The rainbow trout exposed to $\mathrm{Cu}$ showed significant decrease in serum Na level than the control (Shaw et al., 2012). In addition, Oner et al. (2008) documented reduced serum $\mathrm{Na}$ level in $\mathrm{Ag}$ exposed freshwater fish, Oreochromis niloticus.

In the present study, increase in serum $\mathrm{K}$ level of exposed $C$. catla was noted. The $\mathrm{K}$ level in rainbow trout showed a significant increase with metal treatment (Ramsden et al., 2009). Chloride level in serum of exposed fish decreased as compared to control. Logaswamy et al. (2007) reported that the decline in electrolytes, including $\mathrm{Na}$ and $\mathrm{Cl}$, might be caused by histological changes in the gills or instabilities in membrane permeability owing to toxicity.

A time dependent decrease in albumin and total protein content of serum was observed in metal treated fish as compared to control. The exposure of $\mathrm{Cu}$ resulted in more drastic effects as compared to $\mathrm{Cd}$. Hypoproteinemia and hypoalbuminemia observed in metal treated fish could be due to liver and kidney damage. Oronsaye (1989) reported kidney damage in Gasterosteus aculeatus exposed to Cd. In contrast to our finding Oner et al. (2008) observed insignificant alteration in TP in $O$. niloticus intoxicated with $\mathrm{Cd}$ while significant decrease under $\mathrm{Cu}$ exposure.

The high urea level in metal exposed fish was noted in our study. Urea in fish is produced by liver, it is defecated mainly by the gills rather than kidney (Stoskoph, 1993). The higher urea level in our study may be ascribed to gills dysfunction. Gills damage as a result of $\mathrm{Cd}$ intoxication was reported in Gasterosteus aculeatus by Oronsaye (1989). Similarly, Oner et al. (2008) documented increased blood urea in Cd exposed O. niloticus.

Glucose is one of the most sensitive parameter for assessing the stressed state of an organism; its high concentration in the blood indicates that a fish is in stress and is using its energy reserves (Vosyliene, 1999). In our study, the glucose level in the metal treated fish significantly increased by the end of the exposure duration. An increase in serum glucose level under 


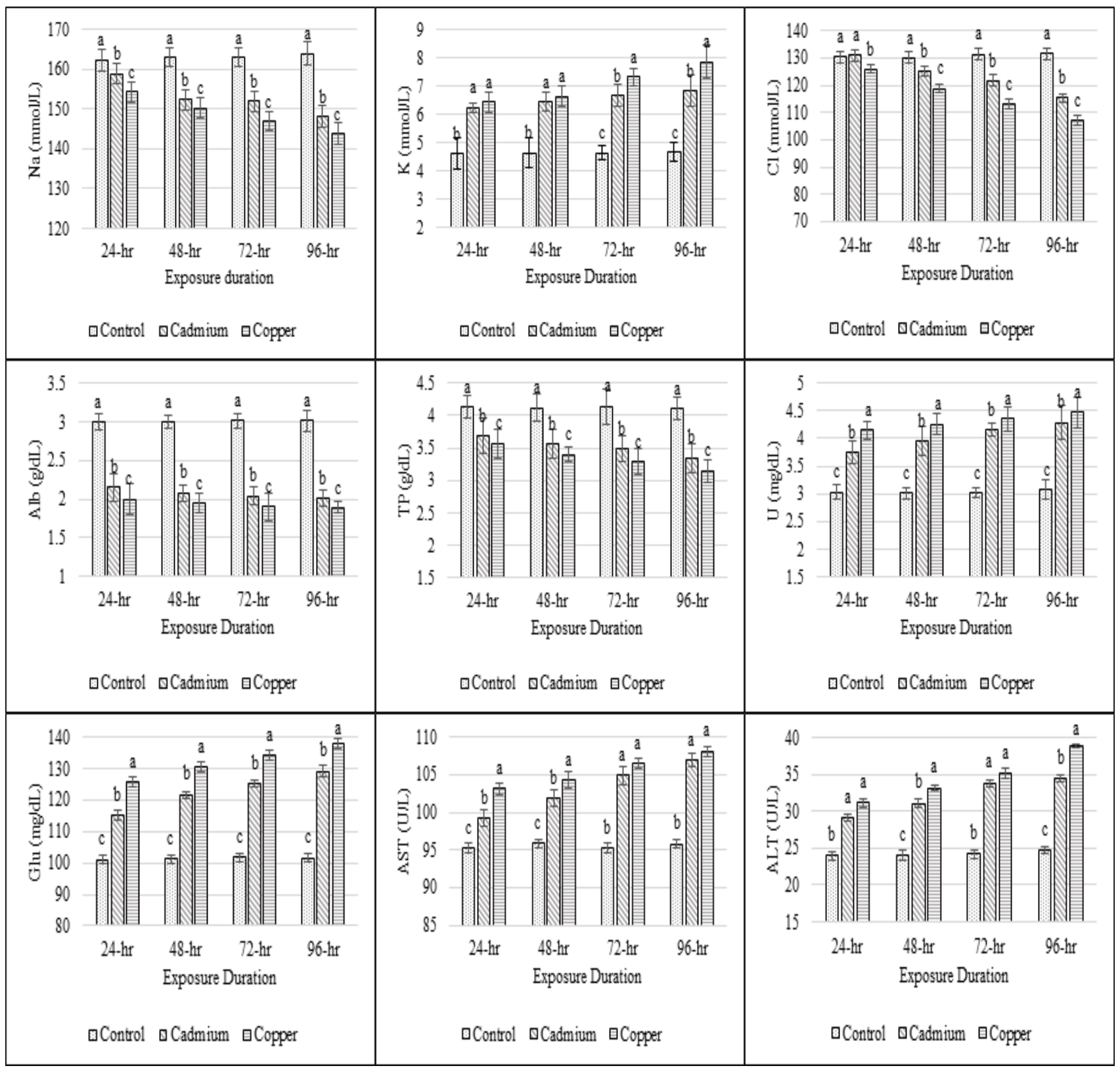

Figure 1. Changes in serum biochemical parameters i.e. sodium (Na), potassium (K), chloride (Cl), albumin (Alb), total protein (TP), urea (U), glucose (Glu), aspartate aminotransferase (AST) and alanine aminotransferase (ALT) of Catla catla after exposure to cadmium and copper.

The bars represent the mean values $( \pm \mathrm{SEM})$. Treatments followed by the same letters are not significantly different $(\mathrm{P}>0.05)$.

the influence of $\mathrm{Cd}$ was linked to a decrease in liver glycogen reserves (Cicik and Engin, 2005).

The ALT and AST activities are often used in the diagnosis of fish diseases and detection of tissue damage caused by metal pollutants (Firat et al., 2011). In this study higher level of AST and ALT was noted in serum of metal exposed fish at all exposure durations. The increase in enzymes levels might be as a result of activation of gluconeogenesis. Increase in
ALT and AST after toxicant exposure in this study is in agreement with previous studies (Abdel-Tawwab et al., 2007; Firat et al., 2011).

The present study accomplishes that exposure of fish, C. catla to cadmium and copper alters the hematological and serum biochemical parameters. The changes in these parameters can be used as biomarkers or as a sensitive tool to determine the toxicity of metals in aquatic environment. The results of this 
study also provide a better understanding of the toxicological endpoint of aquatic pollutants and to establish a safer level of these metals in the aquatic environment in order to protect aquatic organisms.

\section{REFERENCES}

A.P.H.A. 1998. Standard methods for the examination of water and wastewater, $14^{\text {th }}$ Ed. Washington; p.1193.

Abdel-Tawwab, M., M.A.A. Mousa, M.H. Ahmad and S.F.M. Sakr. 2007. The use of calcium pre-exposure as a protective agent against environmental copper toxicity for juvenile Nile tilapia, Oreochromis niloticus (L.). Aquaculture 264:236-246.

Abhijith, B.D., M. Ramesh and R.K. Poopal. 2012. Sublethal toxicological evaluation of methyl parathion on some hematological and biochemical parameters in an Indian major carp Catla catla. Comp. Clin. Pathol. 21:55-61.

Ajani, E.K. and B.U. Akpoilih. 2010. Effect of chronic dietary copper exposure on hematology and histology of common carp (Cyprinus carpio L.). J. Appl. Sci. Environ. Manage. 14:39-45.

Al-Ghanim, K.A. 2011. Impact of nickel (Ni) on hematological parameters and behavioral changes in Cyprinus carpio (common carp). Afr. J. Biotechnol. 10:13860-13866.

Ates, B., I. Orun, Z.S. Talas, G. Durmaz and I. Yilmaz. 2008. Effects of sodium selenite on some biochemical and hematological parameters of rainbow trout (Oncorhynchus mykiss Walbaum 1792) exposed to $\mathrm{Pb}^{2+}$ and $\mathrm{Cu}^{2+}$. Fish Physiol. Biochem. 34:53-59.

ATSDR (Agency for Toxic Substances and Disease Registry). 2003. Toxicological profile for cadmium, U.S. Department of Health and Humans Services, Public Health Service, Centers for Diseases Control, Atlanta, GA.

Carbonell, G. and J.V. Tarazona. 1993. A proposed method to diagnose acute copper poisoning in cultured rainbow trout, (Oncorhynchus mykiss). Sci. Total Environ. Sup. 2:1329-1334.

Cicik, B. and K. Engin. 2005. The effects of cadmium on levels of glucose in serum and glycogen reserves in the liver and muscle tissues of Cyprinus carpio (L., 1758). Turk. J. Vet. Anim. Sci. 29:113-117.

Dhanapakiam, J., V.R. Ramasamy and J.M. Joseph. 2006. Changes in the level of transaminases in Indian major carp, Labeo rohita exposed to sublethal concentration of tannery and distillery effluents. J. Environ. Biol. 27:567570.

Ferrando, M.D. and E. Andreu-Moliner. 1991. Changes in selected biochemical parameters in the brain of the fish Anguilla anguilla (L), exposed to lindane. Bull. Environ. Contam. Toxicol. 47:459-464.
Firat, O., H. Cogun, T. Yuzereroglu, G. Gok, O. Firat, F. Kargin and Y. Kotemen. 2011. A comparative study on the effects of a pesticide (cypermethrin) and two metals (copper and lead) to serum biochemistry of Nile tilapia, Oreochromis niloticus. Fish Physiol. Biochem. 37:657666.

Isani, G., M.L. Falcioni, G. Barucca, D. Sekar, G. Andreani, E. Carpene and G. Falcioni. 2013. Comparative toxicity of $\mathrm{CuO}$ nanoparticles and $\mathrm{CuSO}_{4}$ in rainbow trout. Ecotoxicol. Environ. Safe. 97:40-46.

Kavitha, C., A. Malarvizhi, S.S. Kumaran and M. Ramesh. 2010. Toxicological effects of arsenate exposure on hematological, biochemical and liver transaminases activity in an Indian major carp, Catla catla. Food Chem. Toxicol. 48:2848-2854.

Ketpadung, R. and N. Tangkrock-Olan. 2006. Changes in oxygen consumption and heart rate of the blue swimming crab, Portunus pelagicus (Linnaeus, 1766) following exposure to sublethal concentrations of copper. J. Environ. Biol. 27:7-12.

Kori-Siakpere, O., R.B. Ikomi and M.G. Ogbe. 2012. Variations in acid phosphatase and alkaline phosphatase activities in the plasma of the African Catfish: Clarias gariepinus exposed to sublethal concentrations of potassium permanganate. Asian J. Exp. Biol. Sci. 1:170174.

Kotsanis, N., J. Iliopoulou-Georgudaki and K. KapataZoumbos. 2000. Changes in selected haematological parameters at early stages of the rainbow trout, Oncorhynchus mykiss, subjected to metal toxicants: arsenic, cadmium and mercury. J. Appl. Ichthyol. 16:276-278.

Kousar, S. and M. Javed. 2015. Diagnosis of metals induced DNA damage in fish using comet assay. Pak. Vet. J. 35:168-172.

Larsson, A., C. Haux and M. Sjobeck. 1985. Fish physiology and metal pollution: results and experiences from laboratory and field studies. Ecotoxicol. Environ. Saf. 9:250-281.

Liao, C.M., Y.R. Ju, W.Y. Chen and B.C. Chen. 2011. Assessing the impact of waterborne and diet borne cadmium toxicity on susceptibility risk for rainbow trout. Sci. Total Environ. 409:503-513.

Logaswamy, S., G. Radha, S. Subhashini and K. Logankumar. 2007. Alterations in the levels of ions in blood and liver of freshwater fish, Cyprinus carpio exposed to dimethoate. Environ. Monit. Assess. 131:439-444.

Mazon, A.F., E.A.S. Monteiro, G.H.D. Pinheiro and M.N. Fernandes. 2003. Hematological and physiological changes induced by short-term exposure to copper in the freshwater fish, Prochilodus scrofa. Braz. J. Biol. 62:621-631. 
Nanda, P. and M.K. Behera. 1996. Nickel induced changes in some hemato-biochemical parameters of a catfish, Heteropneustes fossilis. Environ. Ecol. 14:82-85.

Oner, M., G. Atli and M. Canli. 2008. Changes in serum biochemical parameters of freshwater fish Oreochromis niloticus following prolonged metal (Ag, Cd, $\mathrm{Cr}, \mathrm{Cu}, \mathrm{Zn}$ ) exposures. Environ. Toxicol. Chem. 27:360-366.

Oronsaye, J.A. 1989. Histological changes in the kidneys and gills of the stickleback, Gasterosteus aculeatus L, exposed to dissolved cadmium in hard water. Ecotoxicol. Environ. Saf. 17:279- 290.

Pandey, G. 2013. Overviews on diversity of fish. Res. J. Anim. Vet. Fishery Sci. 8:12-18.

Paquin, P.R., V. Zoltay, R.P. Winfield, K.B. Wu, R. Mathew, R.C. Santore and D.M.D. Toro. 2002. Extension of the biotic ligand model of acute toxicity to a physiologicallybased model of the survival time of rainbow trout (Oncorhynchus mykiss) exposed to silver. Comp. Biochem. Physiol. Part C. 133:305-343.

Ramsden, C.S., T.J. Smith, B.J. Shaw and R.D. Handy. 2009. Dietary exposure to titanium dioxide nanoparticles in rainbow trout, (Oncorhynchus mykiss): no effect on growth, but subtle biochemical disturbances in the brain. Ecotoxicol. 18:939-951.

Remyla, S.R., M. Ramesh, K.S. Sajwan and K.S. Kumar. 2008. Influence of zinc on cadmium induced hematological and biochemical responses in a freshwater teleost fish Catla Catla. Fish Physiol. Biochem. 34:169174.

Saravanan, M., K.P. Kumar and M. Ramesh. 2011. Hematological and biochemical responses of freshwater teleost fish Cyprinus carpio (Actinopterygii: Cypriniformes) during acute and chronic sublethal exposure to lindane. Pestic. Biochem. Physiol. 100:206211.

Sayed, E. and A.M. Shokr. 2015. Effect of zinc on hematology and biochemistry of Nile tilapia. J. Chem. Pharm. Res. 7:1943-1950.
Sfakianakis, D.G., E. Renieri, M. Kentouri and A.M Tsatsakis. 2015. Effect of heavy metals on fish larvae deformities: A review. Environ. Res. 137:246-255.

Shaw, B.J., G.A. Al-Bairuty and R.D. Handy. 2012. Effects of water borne copper nanoparticles and copper sulphate on rainbow trout (Oncorhynchus mykiss): physiology and accumulation. Aquat. Toxicol. 116:90-101.

Singh, N.N. and A.K. Srivastava. 2010. Hematological parameters as bioindicators of insecticide exposure in teleosts. Ecotoxicol. 19:838-854.

Skjervold, P.O., S.O. Fjaera, P.B. Ostby and O. Einen. 2001. Live chilling and crowding stress before slaughter of Atlantic salmon (Salmo salar). Aquaculture 192:265280.

Sobecka, E. 2001. Changes in the iron leveling the organs and tissues of catfish, Silurus glanis L. caused by nickel. Acta Ichthyol. Piscat. 31:127-143.

Sridhara, C.N., C. Kamala, S. Samuel and D. Raj. 2008. Assessing risk of heavy metals from consuming food grown on sewage irrigated soils and food chain transfer. Ecotoxicol. Environ. Saf. 69:513-524.

Stoskoph, M. 1993. Fish medicine. St. Louis: W.B. Saunders Company; pp.116-129.

Vincent, S., T. Ambrose, L.C.A. Kumar and M. Selvanayagan. 1996. Heavy metal cadmium influenced anemia in Catla catla. J. Environ. Biol. 17:81-84.

Vosyliene, M.Z. 1999. The effect of heavy metals on haematological indices of fish (survey). Acta. Zool. Litu. 9:76-82.

Vutukuru, S.S. 2003. Chromium induced alterations in some biochemical profiles of the Indian major carp, Labeo rohita (Hamilton). Bull. Environ. Contam. Toxicol. 70:118-123.

Yaqub, S. and M. Javed. 2012. Acute toxicity of waterborne and dietary cadmium and cobalt for fish. Int. J. Agric. Biol. 14:276-280. 